\title{
Angiotensin I-Converting Enzyme (ACE) Inhibitory Activity and ACE Inhibitory Peptides of Salmon (Salmo salar) Protein Hydrolysates Obtained by Human and Porcine Gastrointestinal Enzymes
}

Małgorzata Darewicz $^{1, \dagger, *}$, Justyna Borawska ${ }^{1, \dagger}$, Gerd E. Vegarud ${ }^{2}$, Piotr Minkiewicz ${ }^{1}$ and Anna Iwaniak ${ }^{1}$

1 Department of Food Biochemistry, Faculty of Food Science, University of Warmia and Mazury in Olsztyn, Olsztyn 10-726, Poland;

E-Mails: justyna.borawska@uwm.edu.pl (J.B.); minkiew@uwm.edu.pl (P.M.); ami@uwm.edu.pl (A.I.)

2 Department of Chemistry, Biotechnology and Food Science, Norwegian University of Life Sciences, Ås NO-1432, Norway;

E-Mail: gerd.vegarud@nmbu.no

$\dagger$ These authors contributed equally to this work.

* Author to whom correspondence should be addressed; E-Mail: darewicz@uwm.edu.pl; Tel.: +48-895-245-171; Fax: +48-895-233-945.

Received: 21 May 2014; in revised form: 24 June 2014 / Accepted: 16 July 2014 /

Published: 13 August 2014

\begin{abstract}
The objectives of the present study were two-fold: first, to detect whether salmon protein fractions possess angiotensin I-converting enzyme (ACE) inhibitory properties and whether salmon proteins can release ACE inhibitory peptides during a sequential in vitro hydrolysis (with commercial porcine enzymes) and ex vivo digestion (with human gastrointestinal enzymes). Secondly, to evaluate the ACE inhibitory activity of generated hydrolysates. A two-step ex vivo and in vitro model digestion was performed to simulate the human digestion process. Salmon proteins were degraded more efficiently by porcine enzymes than by human gastrointestinal juices and sarcoplasmic proteins were digested/hydrolyzed more easily than myofibrillar proteins. The ex vivo digested myofibrillar and sarcoplasmic duodenal samples showed $\mathrm{IC}_{50}$ values (concentration required to decrease the ACE activity by $50 \%$ ) of 1.06 and $2.16 \mathrm{mg} / \mathrm{mL}$, respectively. The in vitro hydrolyzed myofibrillar and sarcoplasmic samples showed $\mathrm{IC}_{50}$ values of 0.91 and
\end{abstract}


$1.04 \mathrm{mg} / \mathrm{mL}$, respectively. Based on the results of in silico studies, it was possible to identify 9 peptides of the ex vivo hydrolysates and 7 peptides of the in vitro hydrolysates of salmon proteins of 11 selected peptides. In both types of salmon hydrolysates, ACE-inhibitory peptides IW, IY, TVY and VW were identified. In the in vitro salmon protein hydrolysates an ACE-inhibitory peptides VPW and VY were also detected, while ACE-inhibitory peptides ALPHA, IVY and IWHHT were identified in the hydrolysates generated with ex vivo digestion. In our studies, we documented ACE inhibitory in vitro effects of salmon protein hydrolysates obtained by human and as well as porcine gastrointestinal enzymes.

Keywords: human gastrointestinal enzymes; commercial porcine enzymes; salmon; ACE-inhibitory peptides

\section{Introduction}

Bioactive peptides are inactive when they are encrypted in the parental protein but can be enzymatically released and reveal various biological activities. Bioactive peptides of food origin can act as biological regulators or neurotransmitters. They may express a variety of functions in the gastrointestinal tract or in the intestinal epithelium or after systemic absorption into blood circulation [1]. Angiotensin I-converting enzyme (ACE) (EC 3.4.15.1) is a hypertension-responsible glycoprotein present both in biological fluids and many tissues [2]. ACE inhibitors are the most-studied food peptides and display different biological functions [2,3]. Since fish proteins are structurally diversified, they may serve as a substrate to produce peptides with multifunctional bioactivities [4]. Fish protein hydrolysates have particularly interested food biotechnologists due to the availability of a highly-balanced amino acid content, a high nitrogen content and the presence of biologically active peptides $[5,6]$. Using fish as a source of bioactive peptides provides a novel tool for the introduction of potentially high-value bioactive products.

There are several published studies reporting the presence of bioactivities in enzymatically hydrolysed fish proteins, including ACE inhibitors/antihypertensive peptides [6]. The first report confirming the presence of peptides possessing ACE inhibitory activity in fish protein hydrolysates was published in 1986 for sardine and hairtail [7]. More recently, Gehring et al. [8] reported that fish protein hydrolysates have been shown to inhibit ACE. The peptide LKPNM with an ACE inhibitory activity was found in traditional Japanese food, called katsuobushi, a fermented, smoked skipjack tuna (Katsuwonus pelamis) [6,9]. Actin of skipjack tuna was reported to be a source of 8 peptides with confirmed ACE inhibitory activity [6,9]. Tuna dark muscle treated with various proteases such as alcalase, neutrase, pepsin, papain, $\alpha$-chymotrypsin and trypsin also released ACE inhibitory peptides [10,11]. Six dipeptides recognized as ACE inhibitors/antihypertensive agents were identified in the thermolysin hydrolysate of upstream chum salmon [12]. The same authors [13] demonstrated the antihypertensive effect of salmon muscle hydrolysates on spontaneously hypertensive rats (SHR). Enari et al. [14] examined the antihypertensive effect of salmon hydrolysate containing 20 active di- and tripeptides. Peptides derived from Atlantic salmon skin were reported to possess potent ACE inhibitory 
properties [15]. Ewart et al. [16] used salmon rack proteins and hydrolysed them by alcalase, flavourzyme, fungal protease concentrate, Protease GC106, Multifect Neutral and Protease S-Amano to produce bioactive peptides. Several peptides were found in a salmon protein hydrolysate with sequences as follows: LAF, LTF, IIF, LAY, IAY, VFY, YAY, VLW, IAW, YAL, YNR. All of the peptides showed activity against the ACE.

Farmed salmon (Salmo salar) is a popular food around the world with high nutritional value and a potential application in the prevention of diet-related diseases. There is scientific evidence that diet has a direct relationship with cardiovascular diseases [17]. However, there is no published information available on the ability of salmon proteins to generate ACE inhibitory peptides during gastrointestinal digestion. In the present study, the main purpose was to detect whether salmon protein fractions contain amino acid sequences that have ACE inhibitory properties and whether salmon proteins can release ACE inhibitory peptides during the sequential in vitro hydrolysis (with commercial porcine enzymes) or ex vivo digestion (with human gastrointestinal enzymes). ACE inhibitory activity was also assayed for salmon protein hydrolysates.

\section{Results and Discussion}

This study was divided into three following parts: in silico, ex vivo and in vitro. In the in silico stage we used the information annotated in BIOPEP database to determine the potential biological activity profile to find ACE inhibitory peptides encrypted in selected salmon proteins. Since the presence of "hidden" peptides does not indicate a possible release of those biopeptides, we used computer software to simulate proteolysis to find ACE inhibitory peptides that can potentially be generated according to the specificities of pepsin, trypsin and chymotrypsin. Based on the in silico results, fragments with ACE inhibitory activity were selected and were further identified in the hydrolysates of myofibrillar and sarcoplasmic salmon proteins (Table 1).

Table 1. Amino acid sequences of ACE-inhibitory peptides in the "gastric" and "duodenal" hydrolysates of myofibrillar (M) and sarcoplasmic (S) salmon proteins, $\mathrm{IC}_{50}$ (concentration required to decrease the ACE activity by $50 \%$ ) value and hydrophobicity.

\begin{tabular}{cccc}
\hline Sequences of ACE Inhibitors & Type of Salmon Proteins & $\mathbf{I C}_{\mathbf{5 0}}(\boldsymbol{\mu M})$ & $\begin{array}{c}\text { Hydrophobicity } \\
\text { (Kyte-Doolittle Scale) }\end{array}$ \\
\hline IVY & M, S & 0.48 & 7.4 \\
VW & M, S & 1.4 & 3.3 \\
IY & M, S & 2.1 & 3.2 \\
IW & M, S & 4.7 & 3.6 \\
VY & M, S & 7.1 & 2.9 \\
TVY & M & 15 & 2.2 \\
VFPS & M & 0.46 & 4.6 \\
VTVNPYKWLP & M & 5.5 & -1.3 \\
IWHHT & M & 5.8 & -3.5 \\
YALPHA & M & 9.8 & 1.3 \\
ALPHA & M & 10 & 2.6 \\
\hline
\end{tabular}


ACE inhibitory activity, expressed as a value of $\mathrm{IC}_{50}$, as an indicator of an enzyme's biological response to a dose of a biopeptide, was a criterion for selecting peptides used in further stages of the studies in order to identify them with mass spectrometry. During in vitro studies of peptides with the sequences: TVY, VFPS, VTVNPYKLWLP, YALPHA and ALPHA, they were recognized as ACE inhibitors [18-23]. Peptides with the sequences: IVY, VW, IY, IW, VY and IWHHT were experimentally recognized as antihypertensive i.e., lowering blood pressure in SHR after oral administration [24-27]. The value of hydrophobicity, i.e., one of the physicochemical properties of the examined peptides, was used; this parameter is important during separation assays with RP-HPLC [28] and for the course of ACE inhibition properties [2]. These results are consistent with the results reported by others where ACE peptide inhibitors derived mainly from myofibrillar proteins and collagen were identified $[14,15]$. The presented strategy mimics the so-called "hypothesis-driven proteomics" [29] and it may be named, by analogy, "hypothesis-driven peptidomics". This strategy consists in selecting peptides based on the results of bioinformatics studies with further identification. In the case of biologically active peptides, it is possible to search for fragments that are identical with previously-collected sequences stored in databases [30] or to predict the activity of protein fragments with such software applications as PeptideRanker [31].

The bioinformatics approach presented above was recently successfully applied to study the distribution of ACE-inhibiting peptides within their primary structure of typical food proteins, e.g., from peanuts, amaranthus, whey, champignon mushroom Agaricus bisporus [32-36].

However, it should be noted that the results generated by the in silico simulation of proteolysis were not necessarily confirmed in in vitro studies due to fundamental simplification assumed for the availability of all bonds susceptible to a given enzyme in the polypeptide chain of an examined protein or incomplete data on the specificity of an enzyme. The results of the studies by Thewissen et al. [37] are an example of the failure to implement such a strategy. The experimental data collected during that study did not confirm the theoretical prognoses of the potential to release ACE inhibitors by prolyl endopeptidase (EC 3.4.21.26). The specificity of the enzymes is probably narrower than that described in different repositories, including BIOPEP. The accumulation of as many peptide sequences as possible in databases and their constant updating as well as replenishing information on the specificity of enzymes used in in silico hydrolysis are a factor that determines the level of efficacy and the potential to release biopeptides. The efficacy and verifiability of results generated with in silico assays for predicting the potential to release bioactive peptides from food proteins were discussed in a paper by Vercruysse et al. [38].

\subsection{Protein Content and Sodium Dodecyl Sulfate Polyacrylamide Gel Electrophoresis Analysis of ex Vivo and in Vitro Salmon Protein Hydrolysates}

Figures 1 and 2 show the SDS-PAGE protein profiles of non-digested/non-hydrolyzed and ex vivo digested/in vitro hydrolyzed myofibrillar and sarcoplasmic proteins of salmon, respectively. The results indicated that the protein bands of non-digested/non-hydrolyzed samples have molecular weights ranging from $\sim 20$ to $97 \mathrm{kDa}$ and above. The highest molecular weight of protein bands, i.e., $\sim 97 \mathrm{kDa}$ and above, are likely to represent the subunits of myosin as reported by Ojagh et al. [39]. The protein bands with a molecular weight of $45 \mathrm{kDa}$ are considered as the actin fraction and three lower molecular 
weight bands $(\sim 30, \sim 20$ and $\sim 14 \mathrm{kDa})$ may correspond to the tropomyosin, myosin light chain and globin fractions. These results are in line with the results of the studies by Martinez [40] and Lin [41].

Figure 1. Electrophoretic separation (SDS-PAGE) of the hydrolysates of salmon myofibrillar proteins after ex vivo digestion (ex vivo) or in vitro hydrolysis (in vitro). Standard (St.)-mass marker (97-30 kDa), G-samples after the $2 \mathrm{~h}$ "gastric"/pepsin phase, D-samples after $1 \mathrm{~h}$ "duodenal"/pepsin + Corolase PP phase, "0"-samples after the "chewing" phase (see the "Methods" section).

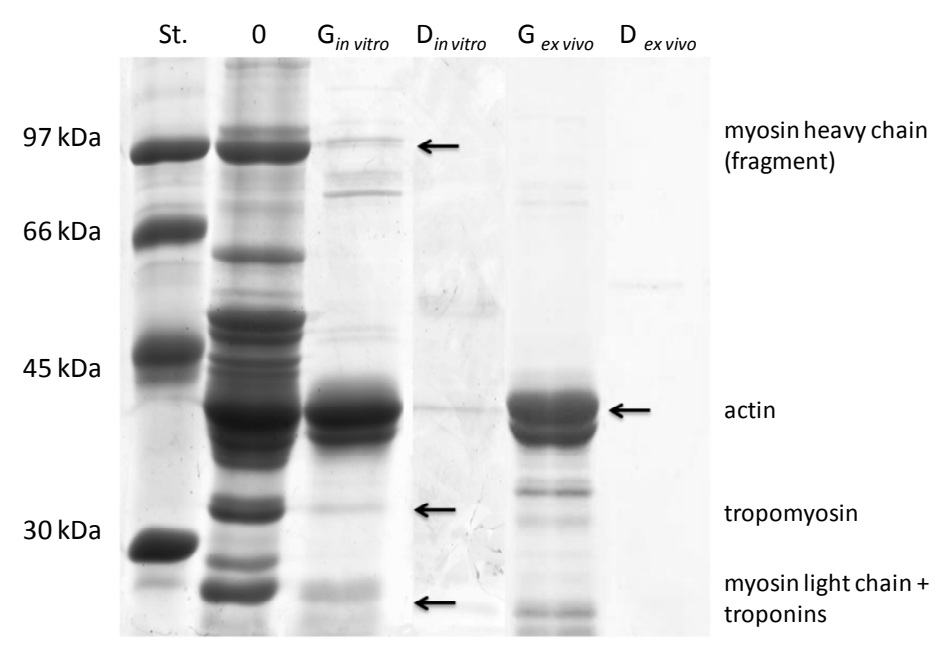

Figure 2. Electrophoretic separation (SDS-PAGE) of the hydrolysates of salmon sarcoplasmic proteins after ex vivo digestion (ex vivo) or in vitro hydrolysis (in vitro). Standard (St.)-mass marker (97-30 kDa), G-samples after the $2 \mathrm{~h}$ "gastric"/pepsin phase, D-samples after $1 \mathrm{~h}$ "duodenal"/pepsin + Corolase PP phase, "0"-samples after the "chewing" phase (see the Methods Section).

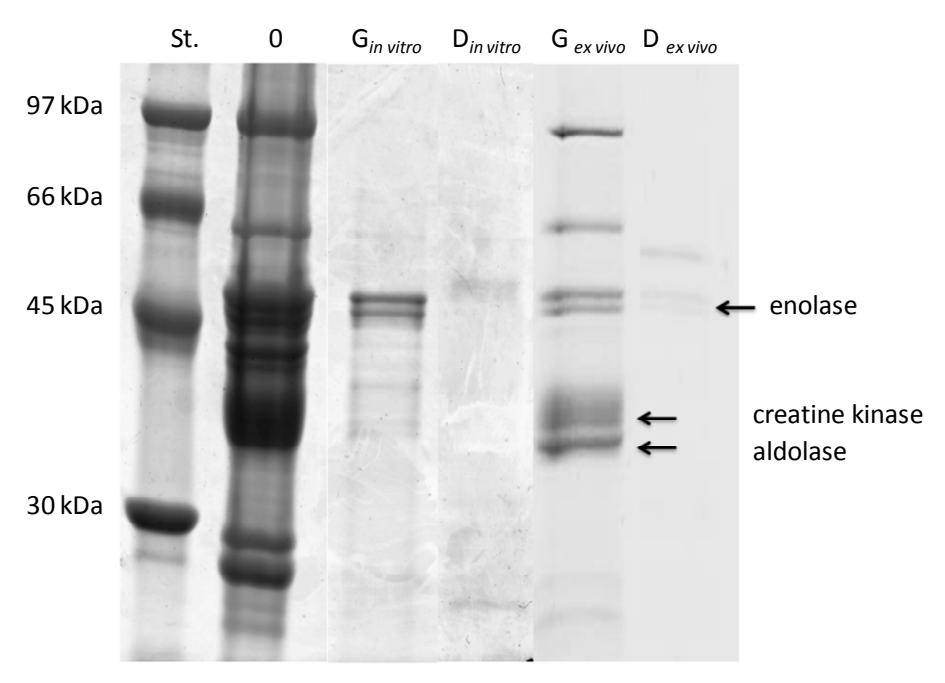

In the gastric or pepsin phase, the highest molecular weight proteins bands $(<45 \mathrm{kDa})$ were significantly hydrolyzed into smaller peptides. The intensity of these protein bands was highly reduced in all hydrolysates. The additional new bands were observed for myofibrillar protein patterns of $\sim 35 \mathrm{kDa}$ and less. It is interesting to note that the protein bands corresponding to the apparent molecular mass of actin remained nearly intact for all hydrolysates, suggesting that this subunit is 
rather stable in the part of the protein and hindered access from gastric juices and pepsin. Similar relations were reported by Eriksen et al. [42] who compared the course of in vitro hydrolysis of milk proteins with pepsin with hydrolysis with human gastric juices.

Duodenal or pepsin A and Corolase PP phases had a significant effect on the proteolysis of both myofibrillar and sarcopasmic salmon proteins. In the presence of duodenal juice and/or Corolase PP, it was observed that the enzymatic hydrolysis led to a gradual breakdown of proteins. Figures 1 and 2 show that the majority of proteins were hydrolysed after the duodenal phase or the pepsin and Corolase PP phase. For instance, Inglingstad et al. [43] observed an almost immediate hydrolysis of casein from sheep, goat and equine milk within 5 minutes of in vitro hydrolysis with human digestive juices.

Similar trends were reported in other studies for hydrolysates prepared from goat milk by Eriksen et al. [44] who indicated that the rate of "duodenal" digestion may be impacted by bile salts from human digestion juices, which are a complex mixture of bile salts and proteases, amylases and lipases in different isoforms in combination with inhibitors, activators, bilirubin and other compounds which may influence the hydrolysis of proteins.

The observed differences are in line with the results presented in Table 2, which shows the percentage of protein remaining intact after ex vivo digestion and in vitro hydrolysis of salmon proteins.

Table 2. The percentage of protein remaining intact after ex vivo digestion and in vitro hydrolysis of salmon proteins.

\begin{tabular}{ccccc}
\hline \multirow{2}{*}{ Hydrolysates } & \multicolumn{2}{c}{ Myofibrillar Proteins } & \multicolumn{2}{c}{ Sarcoplasmic Proteins } \\
\cline { 2 - 5 } & G/Pepsin A & D/Pepsin A and CPP & G/Pepsin A & D/Pepsin A and CPP \\
\hline Ex vivo digestion & $41.03 \pm 1.77$ & $9.82 \pm 1.54$ & $20.06 \pm 0.28$ & $1.09 \pm 0.00$ \\
In vitro hydrolysis & $27.73 \pm 2.70$ & $2.49 \pm 0.85$ & $5.23 \pm 1.17$ & $0.44 \pm 0.14$ \\
\hline
\end{tabular}

$\mathrm{G}$, gastric phase with human gastric juice; $\mathrm{D}$, duodenal phase with human duodenal juice following gastric juice; and CPP, Corolase PP. Data are presented as the means \pm SD. The values in the same row for myofibrillar and sarcoplasmic proteins differ significantly at $p \leq 0.05$. The values in the same column presented separately for myofibrillar and sarcoplasmic gastric/pepsin proteins differ statistically significantly at $p \leq 0.05$.

Myofibrillar proteins were more resistant to digestion or hydrolysis at the two studied stages compared to sarcoplasmic proteins. Such behavior of myofibrillar proteins during depolymerisation is explained by the spatial structure of actomyosin and the presence of lipids which usually hinder the activity of proteolytic enzymes [45].

Based on the amount of intact myofibrillar and sarcoplasmic proteins remaining, porcine pepsin and pepsin followed by Corolase PP were more efficient than human gastric and duodenal juices, respectively. Moreover, the greatest degradation, leaving nearly no intact protein, was observed for hydrolysate of sarcoplasmic salmon proteins after using pepsin A and Corolase PP.

\subsection{Angiotensin I-Converting Enzyme Inhibitory Activity of Hydrolysates}

Salmon myofibrillar and sarcoplasmic proteins were digested using human gastrointestinal juices or hydrolysed using pepsin and Corolase PP. ACE inhibitory activities of hydrolysates are shown in Figure 3. Figure 3 shows that ex vivo hydrolysate from salmon myofibrillar proteins had the ability to inhibit the ACE in the range of $6 \%$ to $25 \%$, whereas the in vitro hydrolysate was in the range 
of $6 \%$ to $66 \%$. In turn, ex vivo hydrolysate from salmon sarcoplasmic proteins had the ability to inhibit the $\mathrm{ACE}$ in the range of $0 \%$ to $26 \%$, whereas the in vitro hydrolysate was in the range of $0 \%$ to $86 \%$. When the ACE inhibitory activity is expressed as the concentration required to inhibit $50 \%$ of ACE activity $\left(\mathrm{IC}_{50}\right)$, ex vivo digested myofibrillar and sarcoplasmic duodenal samples showed $\mathrm{IC}_{50}$ values of 1.06 and $2.16 \mathrm{mg} / \mathrm{mL}$, respectively. In vitro hydrolyzed myofibrillar and sarcoplasmic pepsin + Corolase PP samples showed $\mathrm{IC}_{50}$ values of 0.91 and $1.04 \mathrm{mg} / \mathrm{mL}$, respectively. These results correspond with the results shown in the section: "Protein content and SDS-PAGE analysis of ex vivo and in vitro salmon protein hydrolysates". An increase in the ACE inhibitory activity during a time extension of hydrolysis was also recorded for proteins in Atlantic salmon hydrolyzed with Alcalase and papain [15]. In our study, 60-min salmon duodenal hydrolysates showed a slightly decreased ACE inhibition than that reported by Nakajima et al. [46] when the pepsin and pancreatin hydrolysates of Atlantic salmon showed a $\mathrm{IC}_{50}$ value of $0.791 \mathrm{mg} / \mathrm{mL}$. Extracts from pickled mackerel, fermented mackerel, sardine muscle hydrolysate and hard clam extract were reported to have $\mathrm{IC}_{50}$ values of $0.1-0.4,0.06-0.20,0.25-0.62$ and $0.036-1.090 \mathrm{mg} / \mathrm{mL}$, respectively [46]. Most of the inhibitory peptides derived from marine proteins were reported to be short-chain and were obtained from hydrolysates with a high degradation level [2]. The results presented here suggest that ACE inhibitory peptides can be produced with human gastrointestinal juices as well as commercial porcine enzymes. The ACE-inhibitory activities of digested/hydrolyzed samples increased with the time applied. The gastric stage of digestion followed by a duodenal stage and pepsin stage of hydrolysis followed by Corolase PP stage seem to be the optimal scheme to produce peptides with a high potency of ACE-inhibitory activity. Smaller peptides produced in these final stages of digestion/hydrolysis are known to be more potent ACE inhibitors than larger peptides, likely because they better fit into an ACE active site aimed to change its activity [2]. Furthermore, the results showed significant differences between peptide patterns obtained via ex vivo digestion and in vitro hydrolysis. Human gastrointestinal enzymes generated peptides with weaker ACE inhibitory activity of the hydrolysates than the activity of peptides from hydrolysates obtained with commercial porcine enzymes. These results are in line with the results reported by Eriksen et al. [44] who concluded that commercial enzymes appeared to digest whey proteins more efficiently than human digestive juices.

\subsection{Identification of Angiotensin I-Converting Enzyme (ACE) Inhibitory Peptides}

The "gastric-duodenal" ex vivo and in vitro hydrolysates of myofibrillar and sarcoplasmic salmon proteins were separated with reversed-phase high performance liquid chromatography coupled with mass spectrometry (RP-HPLC-MS/MS). The ACE inhibitory fragments selected based on the results of in silico studies were identified in the hydrolysates of myofibrillar and sarcoplasmic salmon proteins. The analysis of chromatograms generated for the mass-to-charge ratio $(\mathrm{m} / \mathrm{z})$ of many fragment ions derived from a selected precursor ion allowed the experimental retention time for peptides to be determined. The peptides with four amino acid residues or more were regarded as identified if the experimental and predicted retention times did not differ by more than 10\% [28]. Di- and tripeptides for which large differences were found between predicted and experimental retention time were regarded as identified if the experimental retention times in the tested samples were comparable ( $\pm 1 \mathrm{~min})$ to the predicted values. 
For example, it was possible to identify a peptide with ALPHA amino acid sequence and $\mathrm{m} / \mathrm{z}=508.3$ in the gastric-duodenal ex vivo hydrolysate because of the presence of $\mathrm{m} / \mathrm{z}$ values for fragment ions (determined by use of the calculator for fragment ions in peptides) in the analyzed spectra (Figure 4) and the presence of fragment ions in the chromatograms (Figure 5) for which the experimental retention time of 18.59 minutes was comparable $( \pm 10 \%)$ to the predicted time of 17.57 . The $m / z$ value, the type of detected fragment ion [47] and a released neutral particle (ammonium) are highlighted on the chromatograms.

Figure 3. Angiotensin I-converting enzyme (ACE) inhibitory activities (expressed as $\%$ ACE-inhibitory activity of digested (E) and hydrolysed (I) myofibrillar (M) and sarcoplasmic (S) proteins from salmon. 0-a sample after the "chewing" stage, G-a sample after the $2 \mathrm{~h}$ "gastric" stage, D-samples after the $1 \mathrm{~h}$ "duodenal" stage. Value means $\pm \mathrm{SD}$. of three determinations. The pillars denoted with “*” differ statistically at $p<0.05$.

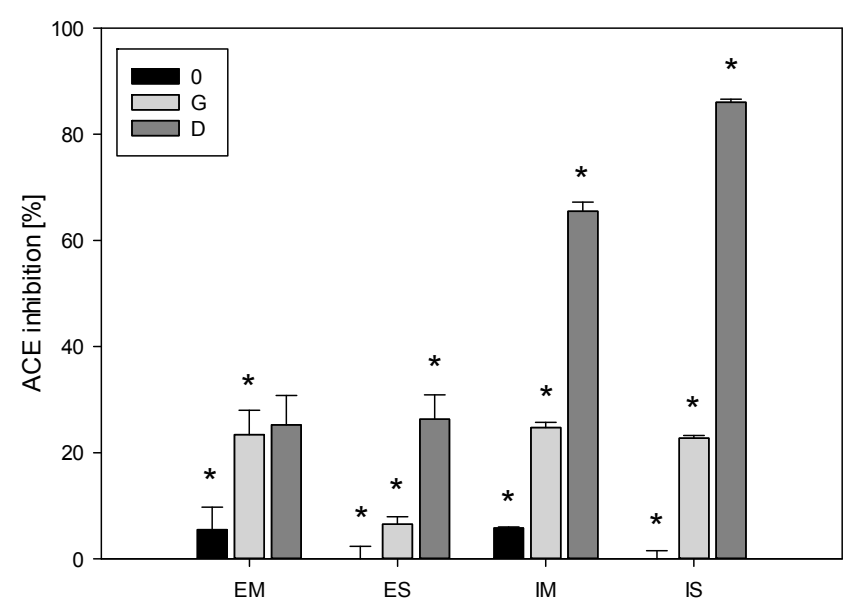

Figure 4. Mass spectra of fragment ions derived from the precursor ion with $\mathrm{m} / \mathrm{z}=508.3$ from the "gastric-duodenal" hydrolysate produced with ex vivo digestion of myofibrillar salmon proteins ( $t_{\mathrm{R}}$ app. $18 \mathrm{~min}$ ) obtained during identification of ALPHA-sequence peptide.

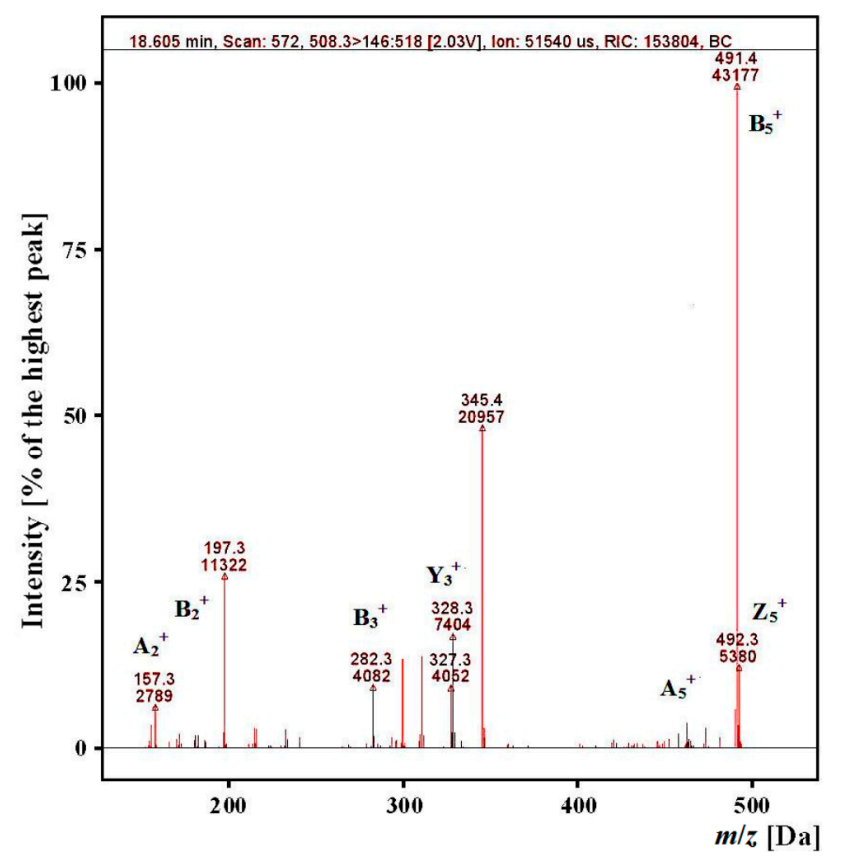


Figure 5. Chromatograms of fragment ions derived from the precursor ions with $m / z=508.3$ from the "gastric-duodenal" hydrolysate generated with ex vivo digestion of myofibrillar salmon proteins obtained during identification of ALPHA sequence peptide, where $* \mathrm{~m} / \mathrm{z}$ for the precursor ion, ** range of $\mathrm{m} / \mathrm{z}$ for investigated fragment ions, $* * *$ a type of ion and $\mathrm{m} / \mathrm{z}$ of the fragment ion, kCounts - count $\times 10^{3}, t_{\mathrm{R}}$ predicted $=17.57 \mathrm{~min}$, $t_{\mathrm{R}}$ experimental $=18.59 \mathrm{~min}$.

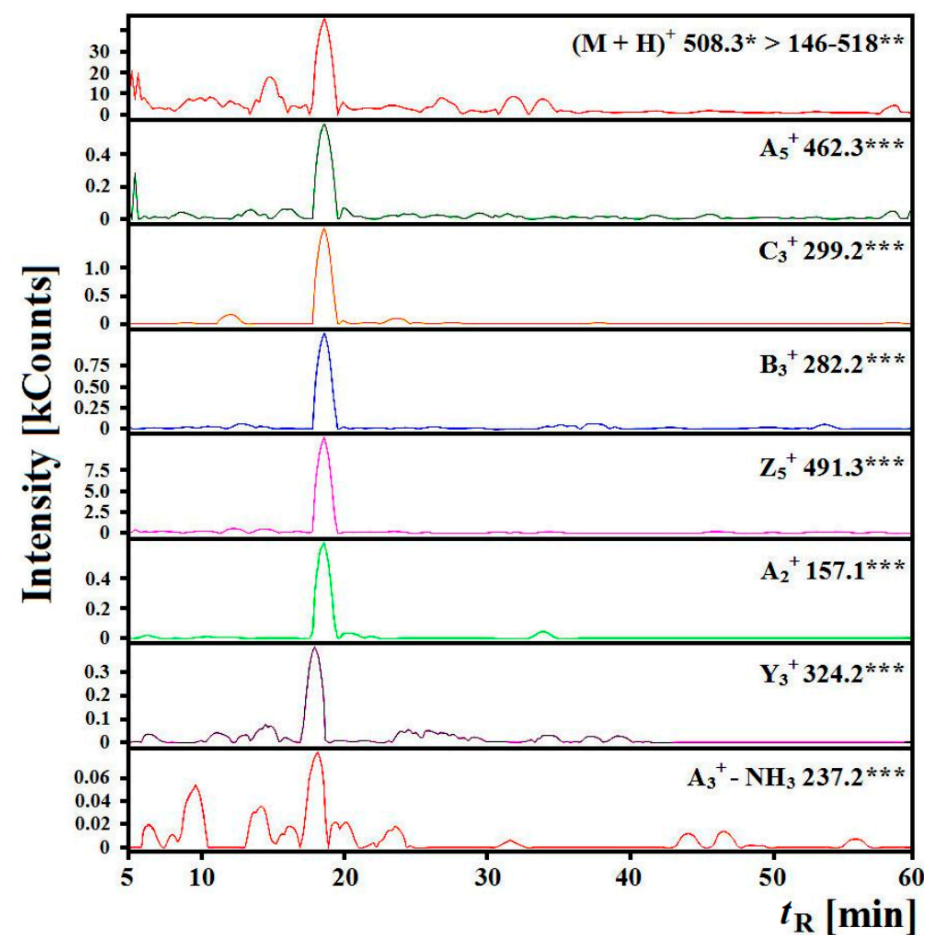

The analysis of chromatograms and mass spectra for investigated $\mathrm{m} / \mathrm{z}$ values of precursor ions and fragment ions led to determine the experimental retention times for all peptides selected according to the procedure described in the section "Methods" (Table 3). During identification, fragment ions of A, $\mathrm{B}, \mathrm{Y}$ and $\mathrm{Z}$ types were most commonly observed. The experimental retention time was not established if different retention times were detected on the chromatograms for fragment ions or no retention times were recorded (e.g., for the LEQQVDDLEGSLEQEKK peptide). Based on the above-mentioned criteria, it was possible to identify 9 peptides from the ex vivo hydrolysates of myofibrillar and sarcoplasmic salmon proteins of 11 peptides selected at the in silico stage.

Table 3. Experimental and predicted retention times $\left(t_{\mathrm{R}}\right)$ for ACE-inhibitory peptides (ACEi) that were searched for in the "gastric-duodenal" hydrolysates obtained after ex vivo digestion of myofibrillar (M) and sarcoplasmic (S) salmon proteins; nd, fragment ions were not detected in a specific time period; “-”, peptides not analyzed because they are not present in the myofibrillar/sarcoplasmic protein sequences.

\begin{tabular}{ccccc}
\hline \multirow{2}{*}{ Sequences } & $\boldsymbol{m} / \boldsymbol{z}$ & \multirow{2}{*}{$\boldsymbol{t}_{\mathrm{R}}$ Predicted (min) $* *$} & \multicolumn{2}{c}{$\boldsymbol{t}_{\mathrm{R}}$ Experimental (min) } \\
\hline ALPHA & 508.3 & $17.57 \pm 1.76$ & $18.59 *$ & $\mathbf{S}$ \\
IVY & 394.2 & - & - & $33.11 *$ \\
IW & 318.2 & - & $30.82 *$ & $30.83 *$ \\
\hline
\end{tabular}


Table 3. Cont.

\begin{tabular}{ccccc}
\hline \multirow{2}{*}{ Sequences } & $\boldsymbol{m} / \boldsymbol{z}$ & \multirow{2}{*}{$\boldsymbol{t}_{\mathrm{R}}$ Predicted (min) $* *$} & \multicolumn{2}{c}{$\boldsymbol{t}_{\mathrm{R}}$ Experimental (min) } \\
\hline IWHHT & 693.3 & $23.58 \pm 2.36$ & $25.10 *$ & $\mathbf{S}$ \\
IY & 295.2 & - & $9.51 *$ & $9.12 *$ \\
TVY & 382.2 & - & $27.08 *$ & - \\
VFPS & 449.2 & $24.50 \pm 2.45$ & $\mathrm{nd}$ & - \\
VTVNPYKWLP & $608.8(2+)$ & $36.69 \pm 3.68$ & $\mathrm{nd}$ & - \\
VW & 304.2 & - & $21.61 *$ & $\mathrm{nd}$ \\
VY & 281.2 & - & $\mathrm{nd}$ & 34.00 \\
YALPHA & 671.4 & $24.04 \pm 2.40$ & 26.98 & - \\
\hline
\end{tabular}

* experimental retention times that allowed the identification of a peptide; and ** prediction of retention time included possible error $\pm 10 \%$ (see the "Methods" section); and (2+) doubly protonated peptide.

The in vitro hydrolysates of myofibrillar and sarcoplasmic salmon proteins were also separated with reversed-phase high performance liquid chromatography coupled with mass spectrometry (RP-HPLC-MS). The identification of an ALPHA peptide in the hydrolysate of myofibrillar salmon proteins was not possible because fragment ions appeared in several different time points whereas at the time that approximated the predicted value, i.e., $18.32 \mathrm{~min}$, few fragment ions flew out, which is further confirmed by the low number of counts at this time point (Figures 6 and 7).

Figure 6. Mass spectra for fragment ions derived from the precursor ion with $\mathrm{m} / \mathrm{z}=508.3$ from the in vitro hydrolysate of myofibrillar salmon proteins (A) after exposure to pepsin and Corolase PP (retention time: app. $18 \mathrm{~min}$ ) obtained during identification of ALPHA sequence peptide.

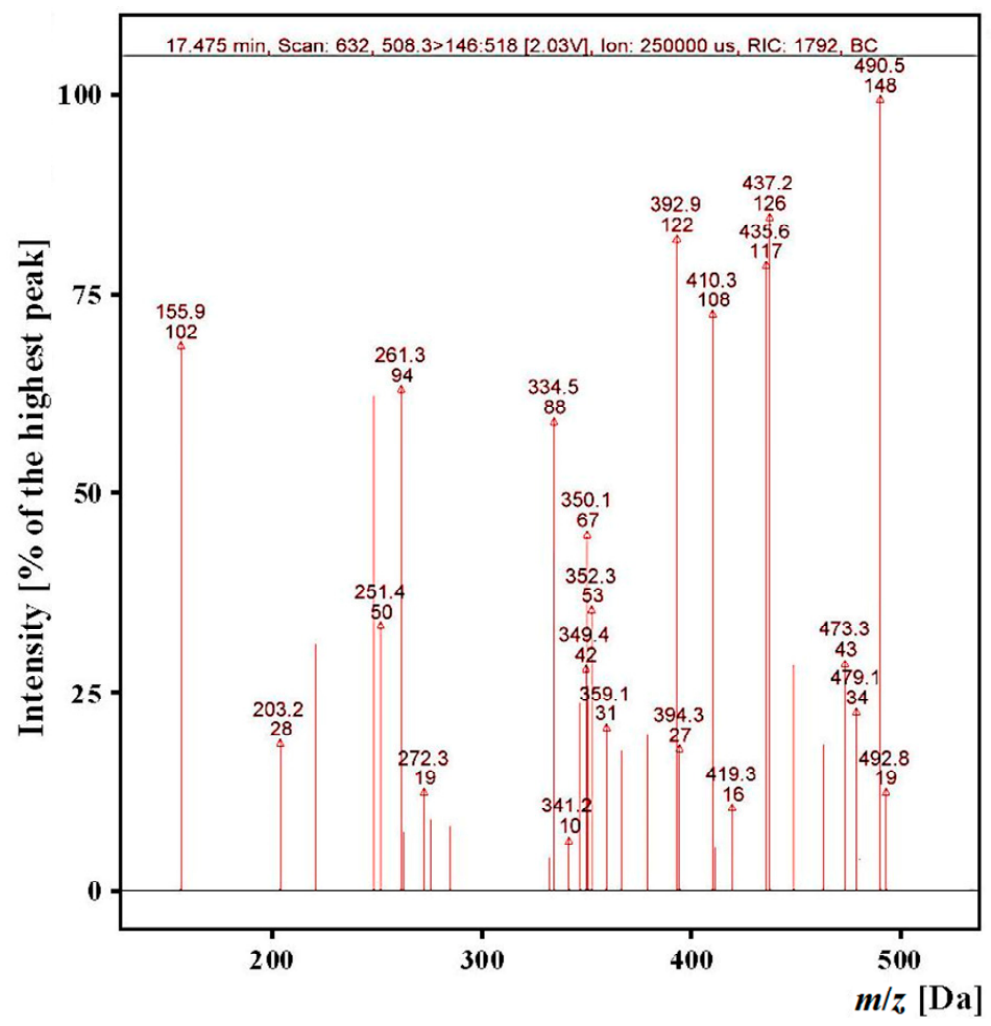


Figure 7. Chromatograms of fragment ions derived from the precursor ion with $m / z=508.3$ from the in vitro hydrolysate of myofibrillar salmon proteins after exposure to pepsin and Corolase PP obtained during identification of ALPHA sequence peptide, where * $\mathrm{m} / \mathrm{z}$ for the precursor ion, ** range of $\mathrm{m} / \mathrm{z}$ for investigated fragment ions, *** a type of ion and $\mathrm{m} / \mathrm{z}$ of the fragment ion, Counts, kCounts-count $\times 10^{3}, t_{\mathrm{R}}$ predicted $=17.57 \mathrm{~min}$.

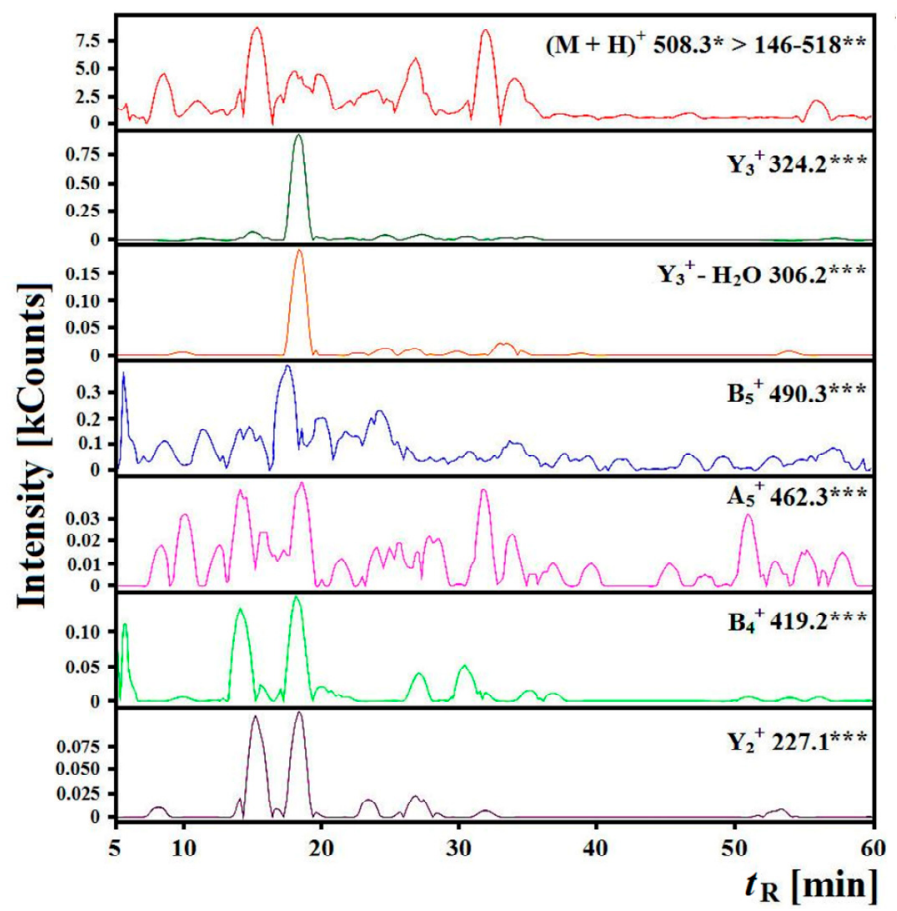

The analysis of chromatograms and mass spectra for demanded values of $m / z$ ratio for the precursor ions and fragment ions allowed the experimental retention times for the majority of the investigated peptides (Table 4) to be determined. Similar to the identification of peptides in the hydrolysates obtained with the use of human digestive juices, fragment ions of $\mathrm{A}, \mathrm{B}, \mathrm{Y}$ and $\mathrm{Z}$ types were most commonly detected [47]. The retention time was not determined if different retention times were present on the chromatograms for fragment ions or retention times were not detected (e.g., for the above-mentioned ALPHA peptide).

Table 4. Experimental and predicted retention times $\left(t_{\mathrm{R}}\right)$ for ACE-inhibitory peptides (ACEi) that were searched for in the hydrolysates generated after in vitro hydrolysis with pepsin and Corolase PP of myofibrillar (M) and sarcoplasmic (S) salmon proteins, nd, fragment ions were not detected in a specific time period; “-”, peptides not analyzed because they are not present in the myofibrillar/sarcoplasmic protein sequences.

\begin{tabular}{ccccc}
\hline \multirow{2}{*}{ Sequences } & $\boldsymbol{m} / \boldsymbol{z}$ & $\boldsymbol{t}_{\mathbf{R}}$ Predicted (min) $* *$ & \multicolumn{2}{c}{$\boldsymbol{t}_{\mathbf{R}}$ Experimental (min) } \\
\cline { 4 - 5 } & & & $\mathbf{M}$ & $\mathbf{S}$ \\
\hline ALPHA & 508.3 & $17.57 \pm 1.76$ & nd & - \\
IVY & 394.2 & - & - & nd \\
IW & 318.2 & - & $29.58 *$ & $31.05 *$ \\
IWHHT & 693.3 & $23.58 \pm 2.36$ & 15.79 & - \\
IY & 295.2 & - & 6.61 & $8.29 *$ \\
TVY & 382.2 & - & $27.26 *$ & - \\
\hline
\end{tabular}


Table 4. Cont.

\begin{tabular}{ccccc}
\hline Sequences & $\boldsymbol{m} / \boldsymbol{z}$ & $\boldsymbol{t}_{\mathrm{R}}$ Predicted $(\mathbf{m i n}) * *$ & \multicolumn{2}{c}{$\boldsymbol{t}_{\mathrm{R}}$ Experimental (min) } \\
\hline VFPS & 449.2 & $24.50 \pm 2.45$ & $\mathrm{nd}$ & $\mathbf{M}$ \\
VPW & 401.2 & - & $6.15 *$ & - \\
VTVNPYKWLP & $608.8(2+)$ & $36.69 \pm 3.68$ & 43.15 & - \\
VW & 304.2 & - & $20.79 *$ & 23.46 \\
VY & 281.2 & - & $\mathrm{nd}$ & $15.13 *$ \\
YALPHA & 671.4 & $24.04 \pm 2.40$ & 27.88 & - \\
\hline
\end{tabular}

* Experimental retention times that allowed the identification of a peptide; and ** Prediction of retention time included possible error $\pm 10 \%$ (see the "Methods" section); $(2+)$ doubly protonated peptide.

Based on the assumed criteria, it was possible to identify 7 peptides from the in vitro hydrolysates of myofibrillar and sarcoplasmic salmon proteins of 11 peptides selected at the in silico stage.

The analysis of the identification results carried out with LC-MS/MS indicate that in both types of salmon hydrolysates, ACE-inhibitory peptides with IW, IY, TVY and VW sequences were identified. In the hydrolysates of salmon proteins obtained with in vitro hydrolysis, an ACE-inhibitory peptides with VPW and VY sequence was additionally detected, whereas ACE-inhibitory peptides with ALPHA, IVY and IWHHT sequences were identified in the hydrolysates produced with ex vivo digestion.

Some of identified sequences were found in other food protein sources and showed ACE inhibitory/antihypertensive effect [2]. For example, the sequences IW, VW and VY were identified in wakame (Undaria pinnatifida). A dose of $1 \mathrm{mg}$ of each peptide/ $\mathrm{kg}$ body weight reduced systolic blood pressure (SBP) in SHR after $3 \mathrm{~h}$ following the administration [25]. Peptides ALPHA and IWHHT were derived from dried bonito treated with thermolysin. These sequences were found to inhibit ACE at the level shown in Table 1 [23]. The sequence IWHHT reduced the systolic blood pressure in SHR at the level of $60 \mathrm{mmHg}$ (dose: $10 \mathrm{mg} / \mathrm{kg}$ body weight) [24]. Tripeptide IVY was found in a wheat germ hydrolysate and the antihypertensive effect of this sequence was tested on mice. An injection of IVY (dose: $5 \mathrm{mg} / \mathrm{kg}$ body weight) caused the maximum arterial blood pressure reduction $(19.2 \mathrm{mmHg})$ after $8 \mathrm{~min}$ and the blood pressure reduction was held for $20 \mathrm{~min}$. Further metabolism of IVY led to obtain ACE-inhibitory dipeptide VY [48]. Therefore, Matsui et al. [48] found the peptide IVY to be a blood pressure reductant due to its antihypertensive effect and the release of VY dipeptide after IVY absorption. The sequences IVY and VY were also derived from Royal Jelly (Apis mellifera), a food regarded as beneficial for health. A single oral administration of VY and IVY (1 and $10 \mathrm{mg} / \mathrm{kg}$ body weight, respectively) significantly reduced the systolic blood pressure in rats within one hour after administration. The reducing effect of these two peptides lasted for $8 \mathrm{~h} \mathrm{[27].}$

The peptides were identified based on an analysis of fragment ions using a mass-to-charge ratio calculated with bioinformatics tools. The identification of peptides composed of at least 4 amino acids was also based on a comparison between theoretical and experimental retention times. The equation described in the section "Methods" that was used to calculate the theoretical retention times for peptides differed from the one included in the cited reference [28]. The reason for these differences was a modification in the SSRCalc software introduced after the paper by Dziuba et al. [28] was released.

During identification of some peptides, different retention times for fragment ions (i.e., opposite to co-elution, which is the impact of different peptides with the same retention time) and the relatively 
few counts compared to the precursor ion were observed. The above-mentioned ions may originate from the following categories of peptides which were specified by Alves et al. [49]: (1) peptides which are isobaric to each other (with the same molecular weight) and cannot be separated by a mass spectrometer based on their mass; (2) peptides with comparable molecular masses that cannot be separated by a spectrometer due to limited apparatus resolution; and (3) peptides with different charges yet with the same or approximate $\mathrm{m} / \mathrm{z}$ ratio (within the resolution range of an apparatus) such as fragment ions typical of the sought compounds.

The identification of peptides with LC-MS/MS based on the detection of fragment ions and a comparison of their retention times is hindered, among others, by the occurrence of non-sequential ions or the regrouping of ions that are missed during analyses with the ion trap [50]. Moreover, in the case of ESI-type ionization that was applied in the present studies, the potential occurrence of ions depends on such parameters as the concentration of an analyzed sample, the flow velocity of a dissolvent or the difference in potentials (i.e., the difference between the voltage of a needle and a shield) [51].

The potential to detect peptides based on theoretical predictions has been discussed [1,3,52,53]. The theoretical potential for using such a strategy was presented by Minkiewicz et al. [3]. The studies involved both the identification of biologically active peptides [1,53] and the application of peptides as markers of allergenic proteins [52].

Although the published results of in silico analyses usually cover successful prognoses [54], there are examples in the literature of discrepancies between the theoretical predictions and observed biological activity of protein hydrolysates [37,55]. Tulipano et al. [55] found a peptide that inhibited dipeptidyl peptidase IV (EC 3.4.14.5) in a whey protein hydrolysate; this peptide was not detected with the profile of the potential activity of any of the examined proteins. Thewissen et al. [37] reported that ACE-inhibitory activity determined for the products of wheat protein hydrolysis with proline endopeptidase (EC 3.4.21.26) was lower than the analogous activity for the products of hydrolysis of the same proteins with thermolysin (EC 3.4.21.64) even though the in silico prediction suggested a different result. Potential reasons behind these discrepancies were discussed by Minkiewicz et al. [53]. The cause of these discrepancies could be the presence of peptides that were not recorded in databases and differences between the predicted and actual specificity of enzymes.

The detection of peptides with the strategy applied in the present study requires proteolytic enzymes to release a sought fragment of the protein chain without hydrolysing the bond inside a given peptide. In addition, this fragment should not undergo chemical or enzymatic modifications. Such modifications may prevent hydrolysis of peptide bonds as well as change the mass of a peptide and fragment ions. Amino acid residues of peptides and proteins may undergo numerous chemical modifications. For instance, the modification of base residues (of lysine and arginine) prevents hydrolysis of the protein chain by trypsin. Modifications of other amino acid residues change the molecular weight of protein fragments, which may prevent their identification with MS and MS/MS [56].

According to Mallick et al. [57], each type of a mass spectrometer detects a different set of peptides. Darewicz et al. [58] reported a case for which the presence of peptides with aromatic amino acids in the hydrolysates of bovine $\beta$-casein was confirmed based on UV spectra even though the analysis with MALDI-ToF-MS did not demonstrate such peptides. Although the potential to detect individual peptides by a specific type of apparatus may be predicted based on the physicochemical properties of amino acid residues, a successful prediction requires analyzing at least hundreds of peptides [57]. 
Peptide VTVNPYKWLP contains bonds theoretically susceptible to trypsin, chymotrypsin and pepsin action as pointed out by Udenigwe and Howard [59]. Its presence in hydrolysate obtained in vitro indicates that some of the above-mentioned bonds were resistant to the proteolysis or only partially hydrolyzed in the conditions applied in this experiment. Absence of the peptide in ex vivo hydrolysate of myofibrillar proteins is in agreement with suggestions of Udenigwe and Howard [59] that joint action of proteolytic enzymes from the human gastrointestinal juices should lead to degradation of this fragment. Peptide VTVNPYKWLP could not be expected in the hydrolysate of sarcoplasmic proteins due to the fact that it is a myosin fragment.

The comparison between the results of peptide identification in the hydrolysates of salmon proteins obtained with human gastrointestinal juices and the results recorded after the application of enzymatic preparations derived from the porcine pancreas suggests that different peptides may be released from the same protein. The differences may be caused by spontaneous modifications of amino acid residues. However, the difference in the specificity of the applied enzymes is the most probable rationale. Among pancreatic serine proteases, high interspecies diversity (structural and functional) and a variety of forms (catalytic, isoenzymes) within a species has been observed [60]. For instance, trypsin in humans is synthesized in three molecular forms whereas there are two forms in the pig. It cannot be excluded that the applied duodenal juice isolated from volunteers might contain enzymes originating from microbiota in the digestive tract. Considering the complexity of digestion, the results obtained for in vivo digestion or, as in the present study, for ex vivo digestion, may differ from in vitro laboratory hydrolysis [61].

\section{Experimental Section}

\subsection{Materials}

Fresh salmon (Salmo salar) fillets were purchased directly from a local market (Olsztyn, Poland) and transported immediately to the laboratory on ice. Fish samples were averaged from fragmented $2 \mathrm{~kg}$ of skinless fillets, washed, packed and stored in a freezer at $-70{ }^{\circ} \mathrm{C}$. Pepsin, sodium dodecyl sulphate (SDS), ACE enzyme extract from rabbit lung, hippuryl-L-histidyl-L-leucine (HHL) and phosphate buffered saline (PBS), pyridine, benzene sulphonyl chloride (BSC) were purchased from Sigma-Aldrich (St. Louis, MO, USA), while LMW-SDS Calibration kit was supplied by GE Healthcare Life Sciences (Little Chalfont, Buckinghamshire, UK), Corolase PP was purchased from AB Enzymes (Darmstadt, Germany) and Protein Assay Dye Reagent Concentrate and bovine serum albumin (BSA) were obtained from Bio-Rad (Hercules, CA, USA). All other chemicals used in the experiments were of analytical grade. Highly purified water was prepared with Milli-Q PLUS (Millipore Corp., Bedford, MA, USA) and used for the preparation of all buffers and solutions.

The amino acid sequences of proteins from salmon (Salmo salar) were taken from the UniProt database available at the website http://www.uniprot.org (accessed between March and June 2012) [62]. Actin and myosin from the myofibrillar fraction, parvalbumin and myoglobin from the sarcoplasmic fraction, hemoglobin, heat shock protein, serum albumin and collagen from the other fractions were taken into consideration. In the UniProt database, there were up to several dozen amino acid sequences of certain proteins with the same names and functions. In order to reject identical sequences, ClustalW2-Multiple Sequence Alignment software (http://www.ebi.ac.uk/Tools/msa/clustalw2/) with standard settings was 
applied $[63,64]$. Amino acid sequences for which the degree of identity was less than $90 \%$ were selected for further studies.

\subsection{Methods}

\subsubsection{In Silico Assay}

The BIOPEP database (http://uwm.edu.pl/biochemia) was updated with sequences of ACE inhibitory peptides originating from food $[65,66]$. The profiles of the potential biological activity of 52 amino acid sequences of salmon proteins selected from the UniProt database were determined. The profiles of potential biological activity were used to define the type and location of ACE inhibitory fragments in the protein chains. Proteolysis simulation in order to assess the possibility of ACE inhibitory peptide release was performed using a procedure built into the BIOPEP database. Data for pepsin (EC 3.4.23.1), trypsin (EC 3.4.21.4) and chymotrypsin (EC 3.4.21.1) were used. The value of hydrophobicity for the obtained peptides was calculated as the sum of hydrophobicity values for individual amino acids contained in the peptides according to the scale by Kyte and Doolitle [67].

\subsubsection{Extraction of Myofibryllar Proteins from Salmon Muscle Tissue}

Myofibrillar proteins were extracted from salmon muscles according to the method described by Martinez et al. [40] with some modification. Cooled and comminuted muscle tissue $(3 \mathrm{~g})$ and $40 \mathrm{~mL}$ of cooled solution A (40 mM TRIS, $\mathrm{pH} 10.5$ ) were homogenized in a Waring 8011E blender (Waring, Torrington, CT, USA) and then centrifuged for $5 \mathrm{~min}$ at $4{ }^{\circ} \mathrm{C}$ and approx. 20,000× $g$ (Sigma $3 \mathrm{~K} 30$ laboratory centrifuge, Sigma Laborzentrifugen $\mathrm{GmbH}$, Osterode, Germany). The supernatant was immediately collected and stored at $-70{ }^{\circ} \mathrm{C}$. Extraction was performed in 3 repetitions which, after mixing and freeze drying, were used as the material for further studies.

\subsubsection{Extraction of Sarcoplasmic Proteins from Salmon Muscle Tissue}

Sarcoplasmic proteins were extracted from salmon muscle tissue according to the method described by Carrera et al. [68] with some modification. $200 \mathrm{~mL}$ of $10 \mathrm{mM}$ Tris-HCl buffer (pH 7.2) with $5 \mathrm{mM}$ PMSF (phenylmethanesulphonyl fluoride) was added to the fish muscle tissue. The sample was then homogenized in a Waring 8011 blender and centrifuged for $20 \mathrm{~min}$ at $4{ }^{\circ} \mathrm{C}$ and $40,000 \times \mathrm{g}$ (Sigma $3 \mathrm{~K} 30$ laboratory centrifuge, Osterode, Germany). The supernatant was then filtered (nylon filters, NL16, $0.22 \mu \mathrm{m}, 47 \mathrm{~mm}$, Whatman ${ }^{\circledR}$, Maidstone, UK) and the filtrate was frozen at $-70{ }^{\circ} \mathrm{C}$. Extraction was done in 3 repetitions. The samples from the repetitions after mixing and freeze-drying were used as the material for further studies.

\subsubsection{Ex Vivo Digestion}

The ex vivo digestion method was performed according to Almaas et al. [69,70] with some modifications. Human gastric juice (HGJ) and duodenal juice (HDJ) were collected according to Ulleberg et al. [71]. All gastric and duodenal enzymes used in the study were obtained from six healthy adults. 
Proteolytic enzyme activity was measured according to methods described by Ulleberg et al. [71]. HGJ was analyzed for pepsin activity at pH 3.0 with hemoglobin (Sigma, St. Louis, MO, USA) as substrate according to Sanchez-Chiang et al. [72]. HDJ was analyzed for total proteolytic activity at pH 8.0 with casein (Merck Co., Darmstadt, Germany) as substrate, as described by Krogdahl and Holm [73] and Kirschenbaum [74]. Briefly, it was done as follows: three concentrations of human gastric or duodenal juices were incubated with substrate for $10 \mathrm{~min}$ at $37^{\circ} \mathrm{C}$, and the reactions were stopped by the addition of trichloroacetic acid. After an overnight sedimentation at $4{ }^{\circ} \mathrm{C}$, the samples were centrifuged for $10 \mathrm{~min}$ at $3000 \times \mathrm{g}$. Analyses were done in triplicates. One unit of enzyme activity was defined as the volume $(\mathrm{mL})$ of gastric or duodenal juice giving a difference in absorbance of 1.0 at $280 \mathrm{~nm}$ in $10 \mathrm{~min}$ at $37^{\circ} \mathrm{C}$. The pepsin activity of $\mathrm{HGJ}$ was $36.85 \mathrm{U} / \mathrm{mL}$, and the total proteolytic activity' in duodenal juice was $12.35 \mathrm{U} / \mathrm{mL}$.

The digestion was carried out in three steps: (1) "chewing" $3 \mathrm{~min}$; (2) "stomach" with a gradual lowering of $\mathrm{pH}$ from 7-5-2.5/2 h; (3) "duodenal" $\mathrm{pH}$ adjusted to 7.0/1 h.

The myofibrillar or sarcoplasmic proteins were diluted up to the final protein concentration of $5 \%(w / v)$ with $0.9 \% \mathrm{NaCl}$ solution at $37{ }^{\circ} \mathrm{C}$. The samples were mixed in a Stomacher 400 (Seward, Norfolk, UK) for $3 \mathrm{~min}$ at $37^{\circ} \mathrm{C}$ and a "blank" (" 0 ") sample was collected. Subsequently, HGJ was added at $15 \mathrm{U} / \mathrm{g}$ of protein. After mixing for $5 \mathrm{~min}$ in a Stomacher $400\left(37^{\circ} \mathrm{C}\right)$, the $\mathrm{pH}$ of the samples was reduced to $5.0(2 \mathrm{M} \mathrm{HCl})$ and after 10 additional min to 2.5 and the samples were then incubated for $105 \mathrm{~min}$. Thereafter, $\mathrm{pH}$ was increased to 7.0 with a $4 \mathrm{M} \mathrm{NaOH}$ solution. At this stage, "gastric" samples ("G") were collected. Next, HDJ was added at $31.2 \mathrm{U} / \mathrm{g}$ of protein and the digested salmon proteins extract was mixed in a Stomacher $400\left(37^{\circ} \mathrm{C}\right)$ for $60 \mathrm{~min}$. "Duodenal" ("D") samples were taken at this stage.

The samples collected at each stage of the experiment were cooled on ice and centrifuged $(9000 \times g$, $20 \mathrm{~min}, 4^{\circ} \mathrm{C}$ ). Supernatants were collected, frozen and then freeze-dried (Freezone 4.5, Labconco, Kansas City, MO, USA) and stored at $-18{ }^{\circ} \mathrm{C}$. The ex vivo digestion procedure was performed in triplicate.

\subsubsection{In Vitro Hydrolysis}

Myofibrillar/sarcoplasmic proteins were mixed and incubated at $37^{\circ} \mathrm{C}$ (Memmert $100-800$ laboratory incubator, Schwabach, Germany) in Nunc-type tubes with a KL-942 laboratory rocker-shaker (JWE Electronic, Warsaw, Poland). An enzymatic pepsin preparation was used instead of HGJ in an amount corresponding to $15 \mathrm{U}$ per gram of hydrolyzed protein, whereas Corolase PP was added at an amount of 31.2 U/g of hydrolyzed protein. The activity of pepsin and Corolase PP were assumed based on the manufacturer's information. The Corolase PP solution at a concentration of $50 \mathrm{mg} / \mathrm{mL}$ contained $111.6 \mathrm{mg}$ of bile salts $/ \mathrm{mL}$ and $0.1 \mathrm{M} \mathrm{NaHCO}_{3}$. Similarly to ex vivo digestion, the "stomach" stage lasted $120 \mathrm{~min}$, whereas the "Corolase PP" stage took $60 \mathrm{~min}$ at $\mathrm{pH}$ 7. The samples collected after each stage of in vivo hydrolysis were cooled in ice and centrifuged $\left(9000 \times \mathrm{g}, 20 \mathrm{~min}, 4{ }^{\circ} \mathrm{C}\right.$; Sigma $3 \mathrm{~K} 30$ laboratory centrifuge, Osterode, Germany). Supernatants were collected, frozen and then freeze-dried (Freezone 4.5, Labconco, Kansas City, MO, USA) and stored at $-18{ }^{\circ} \mathrm{C}$. The procedure of in vitro hydrolysis was conducted in triplicate. 


\subsubsection{Protein Content}

The protein samples were measured with a microprotein assay according to Bradford [75], using diluted Protein Assay Dye Reagent Concentrate and BSA to determine the standard curve. Samples or BSA $(0.02 \mathrm{~mL})$ were mixed with Bradford Dye Reagent ( $1 \mathrm{~mL}$, Bio-Rad, Hercules, CA, USA). The absorbance at $595 \mathrm{~nm}$ was measured after 5-10 min against a reagent blank (GENESYS 6, Thermo Scientific, San José, CA, USA).

The protein concentration in each sample was calculated based on a standard curve. The analyses were performed in triplicate and presented as average values.

\subsubsection{Sodium Dodecyl Sulfate Polyacrylamide Gel Electrophoresis (SDS-PAGE)}

SDS-PAGE was carried out to evaluate the protein profile after each digestion step ("Mini-PROTEAN", Bio-Rad, Hercules, CA, USA). The assay was performed according to standard protocols [76], using $12 \%$ and $15 \%$ separating acrylamide gels. The molecular mass markers used were the Low MW standard kit (97,000-14,400 Da, GE Healthcare Life Sciences, Little Chalfont, Buckinghamshire, UK). Staining was performed according to the standard Coomassie procedure (Bio-Rad, Hercules, CA, USA).

\subsubsection{Angiotensin I-Converting-Enzyme (ACE) Inhibitory Activity}

ACE inhibitory activity was assayed by measuring the release of HA from the substrate HHL according to Jimsheena and Gowda [77]. The assay mixture contained $0.125 \mathrm{~mL}$ of a $0.05 \mathrm{M}$ sodium borate buffer ( $\mathrm{pH}$ 8.2), containing $0.3 \mathrm{M} \mathrm{NaCl}, 0.05 \mathrm{~mL}$ of $5 \mathrm{mM} \mathrm{HHL}$ and $0.025 \mathrm{~mL}$ of ACE (2.5 mU), which was pre-incubated with different sample concentrations. The reaction was stopped after incubation at $37{ }^{\circ} \mathrm{C}$ for $30 \mathrm{~min}$ by the addition of $0.2 \mathrm{~mL}$ of $1 \mathrm{M} \mathrm{HCl}$. Pyridine $(0.4 \mathrm{~mL})$ was added followed by $0.2 \mathrm{~mL}$ of BSC (the order of addition of reagents is critical) and mixed by inversion for $1 \mathrm{~min}$ and cooled on ice. Absorbance was measured at $410 \mathrm{~nm}$ in a spectrophotometer (GENESYS 6, Thermo Scientific, San José, CA, USA).

The degree of ACE inhibition (\%) was calculated with the following equation [78]:

$$
\text { ACE inhibition }(\%)=\frac{A_{1}-A_{2}}{A_{1}-A_{3}} \times 100
$$

where: $A_{1}$-absorbance of the ACE solution without an inhibitor (salmon protein hydrolysate); $A_{2}$ - absorbance of the tested sample of salmon protein hydrolysate; $A_{3}$-absorbance of HHL solution (a buffer was added instead of the ACE solution and sample).

The values presented in the paper are the mean of triplicate analyses.

The $\mathrm{IC}_{50}$ value is defined as the concentration required to decrease the ACE activity by $50 \%$. The percent inhibition curves were plotted using a minimum of five determinations for each sample concentration and the mean $\mathrm{IC}_{50}$ values were performed using GraphPad Prism ${ }^{\circledR}$ v. 5.02 for Windows (GraphPad Software, La Jolla, CA, USA). 


\subsubsection{Identification of Bioactive Peptides Using RP-HPLC-MS}

The obtained protein hydrolysates were analyzed with reversed phase high performance liquid chromatography coupled with mass spectrometry (RP-HPLC-MS). A set manufactured by VARIAN ${ }^{\circledR}$ (Palo Alto, CA, USA) was used in the studies; this set was composed of two pumps 212-L, a ProStar 410 autosampler, a Degassit degasser (MetaChem Technologies ${ }^{\circledR}$, Torrance, CA, USA), an ESI-IT-MS-type VARIAN 500-MS mass spectrometer (with electrospraying ionization and the ion trap) and a LC/MS 12-2 nitrogen generator (Domnick Hunter Scientific ${ }^{\circledR}$, Lancaster, NY, USA). Separation was performed on a Jupiter Proteo column (Phenomenex, Torrance, CA, USA) with the following parameters: $250 \mathrm{~mm} \times 2 \mathrm{~mm}$ in size, $4 \mu \mathrm{m}$ granule diameter and a $90 \AA$ pore diameter that was developed to separate analytes with a low concentration of trifluoroacetic acid (TFA). $0.01 \%(v / v)$ TFA solution in water (Solution A) and in acetonitrile (Solution B) was used in a gradient of Solution B $0 \%-40 \%$ for $60 \mathrm{~min}$. Afterwards, the column was washed and balanced with the following gradient: $40 \%-100 \% \mathrm{~B}$ in 60 to $65 \mathrm{~min}, 100 \% \mathrm{~B}$ in 65 to $70 \mathrm{~min}$, from $100 \%$ to $0 \% \mathrm{~B}$ in 70 to $71 \mathrm{~min}$ and $0 \% \mathrm{~B}$ in 71 to $80 \mathrm{~min}$. Separations were performed at $30{ }^{\circ} \mathrm{C}$ with $10 \mu \mathrm{L}$ injection volume and flow velocity of $200 \mu \mathrm{L} / \mathrm{min}$. The data was collected in 5-60 min. The results of analyses were stored and processed with MS WorkStation v. 6.9 software [79].

The samples of hydrolysates were dissolved in deionized water (a Synergy deionizer, Millipore ${ }^{\circledR}$, Darmstadt, Germany) up to a concentration of $12.5 \mathrm{mg} / \mathrm{mL}$ of lyophilisate. The prepared solutions were centrifuged $(10 \mathrm{~min}, 10,000 \times \mathrm{g})$ at room temperature. During the processing of the chromatograms, the method by Savitzky and Golay [80] that was included in the software was applied for smoothing 11 neighboring points, i.e., the maximum number that may be covered by the application.

The recorded retention times were compared with the values predicted with SSRCalc software (http:/hs2.proteome.ca/SSRCalc/SSRCalcX.html) [81-83] with a correction calculated according to the algorithm presented by Dziuba et al. [28] with the following equation:

$$
t_{R \text { predicted }}=0.0002 \times t_{R \text { SSRCalc }}^{3}-0.0085 \times t_{R \text { SSRCalc }}{ }^{2}+1.0415 \times t_{R \text { SSRCalc }}+8.6434
$$

ExcelTM v. 2007 software (Microsoft, Redmond, WA, USA) was used to adjust the third degree polynomial.

The molecular weights of salmon protein hydrolysis products were measured in LC-MS mode [79]. The identification of peptides was carried out with the LC-ESI-MS/MS procedure. The mass-to-charge ratio $(\mathrm{m} / \mathrm{z})$ for sought peptides and their fragment ions was determined with a Fragment Ion Calculator application that is available online (http://db.systemsbiology.net:8080/proteomicsToolkit/ FragIonServlet.html) [84]. During separations, the voltages of the needle and shield were 5000 and $600 \mathrm{~V}$, respectively, the pressure of spraying and drying gas was 35 and 30 psi, respectively, and the drying gas temperature was $390^{\circ} \mathrm{C}$. A single scan was averaged based on six microscans and the time of a single scan was $22.86 \mathrm{~s}$. The data was collected for $60 \mathrm{~min}$ at $0.04 \mathrm{~Hz}$. The range of the analyzed mass-to-charge ratios was 100-2000 Da.

The peptides were identified using LC-MS/MS analysis based on the mass-to-charge ratio $(\mathrm{m} / \mathrm{z})$ and the analyses of mass spectra for fragment ions derived from the precursor ion during fragmentation. The peaks that corresponded to individual ions at the same retention time allowed us to identify a given peptide [85]. 
The predicted retention times for the peptides with more than a four-amino acid chain were determined with Sequence Specific Retention Calculator (SSRCalc) application with a personal correction. No predicted retention times were established for di- and tripeptides as the applied application does not allow to calculate the retention times for sequences composed of two or three amino acid residues.

\subsubsection{Statistical Analysis}

The results of the analyses are presented as means \pm standard deviation. Statistical analyses were conducted with Statistica v. 10 (StatSoft, Krakow, Poland) using ANOVA Kruskal-Wallis test with a significance level of $p<0.05$.

\section{Conclusions}

In recent years, increased attention has been paid to the biological activity of peptides of marine origin. Some ACE inhibitors that were the products of in vitro as well as ex vivo digestion of salmon proteins have become known for their anti-hypertensive bioactivity. The present study assesses the use of protein-rich salmon muscle tissue in order to exploit "hidden" ACE-inhibitory peptides. In this study, we showed that a computer-aided approach can be combined with an experimental approach for hidden ACE inhibitory peptides from salmon muscle tissue. The present results showed significant differences between peptide patterns obtained via ex vivo digestion and in vitro hydrolysis. Human gastrointestinal enzymes generated peptides with weaker ACE inhibitory activity of the hydrolysates than the activity of peptides from hydrolysates obtained with commercial porcine enzymes. Considering the complexity of digestion, the results obtained for in vivo digestion or, as in the present study, for ex vivo digestion, may differ from in vitro laboratory hydrolysis. Although ACE-inhibitory peptides from marine sources are weaker in ACE inhibition than synthetic drugs, the peptides derived from fish sources are often consumed in a diet. Some of the peptides found in this experiment were previously described as revealing antihypertensive activity in vivo in spontaneously hypertensive rats. Our results provide a basis for further clinical animal and human studies.

\section{Acknowledgments}

The authors would like to thank Irene Comi for the aspiration of human digestive juices in cooperation with Oestfold Hospital Trust, Norway, and for analyzing all enzyme activities. J.B. is grateful to G.E.V. from Norwegian University of Life Sciences, Norway, for her supervising help during the stay in Norway. This research was supported by grants from the National Science Center in Poland (project no. N N312 465240), University of Warmia and Mazury (528-0712-0882, 528-0712-0809) and co-financed by technical assistance funds of the EEA Financial Mechanism and the Norwegian Financial Mechanism within the framework of the Scholarship and Training Fund.

\section{Author Contributions}

J.B., M.D., P.M. and A.I. performed experiments and data treatments. Writing was done by M.D., J.B., G.E.V., P.M. and A.I., and management and submission tasks were done by J.B. and M.D. 


\section{Conflicts of Interest}

The authors declare no conflict of interest.

\section{References}

1. Darewicz, M.; Dziuba, B.; Minkiewicz, P.; Dziuba, J. The preventive potential of milk and colostrum proteins and protein fragments. Food Rev. Int. 2011, 27, 357-388.

2. Iwaniak, A.; Minkiewicz, P.; Darewicz, M. Food-originating ACE inhibitors, including antihypertensive peptides, as preventive food components in blood pressure reduction. Compr. Rev. Food Sci. Food Saf. 2014, 13, 114-134.

3. Minkiewicz, P.; Dziuba, J.; Darewicz, M.; Iwaniak, A.; Dziuba, M.; Nałęcz, D. Food Peptidomics. Food Technol. Biotechnol. 2008, 46, 1-10.

4. Harnedy, P.A.; FitzGerald, R.J. Bioactive peptides from marine processing waste and shellfish: A review. J. Funct. Foods 2012, 4, 6-24.

5. Chalamaiah, M.; Kumar, B.D.; Hemalatha, R.; Jyothirmayi, T. Fish protein hydrolysates: Proximate composition, amino acid composition, antioxidant activities and applications: A review. Food Chem. 2012, 135, 3020-3038.

6. Ryan, J.T.; Ross, R.P.; Bolton, D.; Fitzgerald, G.F.; Stanton, C. Bioactive peptides from muscle sources: Meat and fish. Nutrients 2011, 3, 765-791.

7. Suetsuna, K.; Osajima, K. The inhibitory activities against angiotensin I-converting enzyme of basic peptides originating from sardine and hair tail meat. Bull. Jpn. Soc. Sci. Fish. 1986, 52, 1981-1984.

8. Gehring, C.; Davenport, M.; Jaczynski, J. Functional and nutritional quality of protein and lipid recovered from fish processing by-products and underutilized aquatic species using isoelectric solubilization/precipitation. Curr. Nutr. Food Sci. 2009, 5, 17-39.

9. Vercruysse, L.; van Camp, J.; Smagghe, G. ACE inhibitory peptides derived from enzymatic hydrolysates of animal muscle protein: A review. J. Agric. Food Chem. 2005, 53, 8106-8115.

10. Qian, Z.J.; Je, J.Y.; Kim, S.K. Antihypertensive effect of angiotensin I converting enzyme-inhibitory peptide from hydrolysates of Bigeye tuna dark muscle, Thunnus obesus. J. Agric. Food Chem. 2007, 55, 8398-8403.

11. Lee, S.H.; Qian, Z.J.; Kim, S.K. A novel angiotensin I converting enzyme inhibitory peptide from tuna frame protein hydrolysate and its antihypertensive effect in spontaneously hypertensive rats. Food Chem. 2010, 118, 96-102.

12. Ono, S.; Hosokawa, M.; Miyashita, K.; Takahashi, K. Isolation of peptides with angiotensin I-converting enzyme inhibitory effect derived from hydrolysate of upstream chum salmon muscle. J. Food Sci. 2003, 68, 1611-1614.

13. Ono, S.; Hosokawa, M.; Miyashita, K.; Takahashi, K. Inhibition properties of dipeptides from salmon muscle hydrolysate on angiotensin I-converting enzyme. Int. J. Food Sci. Technol. 2006, $41,383-386$. 
14. Enari, H.; Takahashi, Y.; Kawarasaki, M.; Tada, M.; Tatsuta, K. Identification of angiotensin I-converting enzyme inhibitory peptides derived from salmon muscle and their antihypertensive effect. Fish. Sci. 2008, 74, 911-920.

15. Gu, R.Z.; Li, C.Y.; Liu, W.Y.; Yi, W.X.; Cai, M.Y. Angiotensin I-converting enzyme inhibitory activity of low-molecular-weight peptides from Atlantic salmon (Salmo salar L.) skin. Food Res. Int. 2011, 44, 1536-1540.

16. Ewart, H.S.; Dennis, D.; Potvin, M.; Tiller, C.; Fang, L.; Zhang, R.; Zhu, X.; Curtis, J.M.; Cloutier, S.; Du, G.; et al. Development of a salmon protein hydrolysate that lowers blood pressure. Eur. Food Res. Technol. 2009, 229, 561-569.

17. Alissa, E.M.; Ferns, G.A. Functional foods and nutraceuticals in the primary prevention of cardiovascular diseases. J. Nutr. Metabol. 2012, 2012, 569486.

18. Rousseau-Ralliard, D.; Goirand, F.; Tardivel, S.; Lucas, A.; Algaron, F.; Mollé, D.; Robert, V.; Auchere, D.; Boudier, J.F.; Gailard, J.L.; et al. Inhibitory effect of $\alpha_{\mathrm{S}^{-}}$and $\alpha_{\mathrm{S} 2}$-casein hydrolysates on angiotensin I-converting enzyme in human endothelial cells in vitro, rat aortic tissue ex vivo, and renovascular hypertensive rats in vivo. J. Dairy Sci. 2010, 93, 2906-2921.

19. Tauzin, J.; Miclo, L.; Gaillard, J.L. Angiotensin-I-converting enzyme inhibitory peptides from tryptic hydrolysate of bovine $\alpha_{\mathrm{s} 2}$-casein. FEBS Lett. 2002, 531, 369-374.

20. Loponen, J. Angiotensin converting enzyme inhibitory peptides in Finnish cereals: A database survey. Agric. Food Sci. 2004, 13, 39-45.

21. Terashima, M.; Oe, M.; Ogura, K.; Matsumura, S. Inhibition strength of short peptides derived from an ACE inhibitory peptide. J. Agric. Food Chem. 2011, 59, 11234-11237.

22. Bauchart, C.; Morzel, M.; Chambon, C.; Mirand, P.P.; Reynès, C.; Buffière, C.; Rèmond, D. Peptides reproducibly released by in vivo digestion of beef meat and trout flesh in pigs. Br. J. Nutr. 2007, 98, 1187-1195.

23. Yokoyama, K.; Chiba, H.; Yoshikawa, M. Peptide inhibitors for angiotensin I-converting enzyme from thermolysin digest of dried bonito. Biosci. Biotechnol. Biochem. 1992, 56, 1541-1545.

24. Fujita, H.; Yokoyama, K.; Yoshikawa, M. Classification and antihypertensive activity of angiotensin I-converting enzyme inhibitory peptides derived from food proteins. J. Food Sci. 2000, 65, 564-569.

25. Sato, M.; Hosokawa, T.; Yamaguchi, T.; Nakano, T.; Muramoto, K.; Kahara, T.; Funayama, K.; Kobayashi, A.; Nakano, T. Angiotensin I-converting enzyme inhibitory peptides derived from wakame (Undaria pinnatifida) and their antihypertensive effect in spontaneously hypertensive rats. J. Agric. Food Chem. 2002, 50, 6245-6252.

26. Marczak, E.D.; Usui, H.; Fujita, H.; Yang, Y.; Yokoo, M.; Lipkowski, A.W.; Yoshikawa, M. New antihypertensive peptides isolated from rapeseed. Peptides 2003, 24, 791-798.

27. Tokunaga, K.; Yoshida, C.; Suzuki, K.; Maruyama, H.; Futamura, Y.; Araki, Y.; Mishima, S. Antihypertensive effect of peptides from royal jelly in spontaneously hypertensive rats. Biol. Pharm. Bull. 2004, 27, 189-192.

28. Dziuba, J.; Minkiewicz, P.; Mogut, D. Determination of theoretical retention times for peptides analyzed by reversed-phase high-performance liquid chromatography. Acta Sci. Pol. Technol. Aliment. 2011, 10, 209-221. 
29. Schmidt, A.; Claassen, M.; Aebersold, R. Directed mass spectrometry: Towards hypothesis-driven proteomics. Curr. Opin. Chem. Biol. 2009, 13, 510-517.

30. Minkiewicz, P.; Dziuba, J.; Darewicz, M.; Iwaniak, A. Online programs and databases of peptides and proteolytic enzymes-A brief update for 2007-2008. Food Technol. Biotechnol. 2009, 47, 345-355.

31. Mooney, C.; Haslam, N.J.; Pollastri, G.; Shields, D.C. Towards the improved discovery and design of functional peptides: Common features of diverse classes permit generalized prediction of bioactivity. PLoS One 2012, 7, e45012.

32. Jimsheena, V.K.; Gowda, L.R. Angiotensin I-converting enzyme (ACE) inhibitory peptides derived from arachin by simulated gastric digestion. Food Chem. 2011, 125, 561-569.

33. White, B.L.; Sanders, T.H.; Davis, J.P. Potential ACE-inhibitory activity and nanoLC-MS/MS sequencing of peptides derived from aflatoxin contaminated peanut meal. LWT-Food Sci. Technol. 2014, 56, 537-542.

34. Quiroga, A.V; Aphalo, P.; Ventureira, J.L.; Martínez, E.N.; Añón, M.C. Physicochemical, functional and angiotensin converting enzyme inhibitory properties of amaranth (Amaranthus hypochondriacus) 7S globulin. J. Sci. Food Agric. 2012, 92, 397-403.

35. Welderufael, F.T.; Gibson, T.; Methven, L.; Jauregi, P. Chemical characterisation and determination of sensory attributes of hydrolysates produced by enzymatic hydrolysis of whey proteins following a novel integrative process. Food Chem. 2012, 134, 1947-1958.

36. Lau, C.C.; Abdullah, N.; Shuib, A.S.; Aminudin, N. Novel angiotensin I-converting enzyme inhibitory peptides derived from edible mushroom Agaricus bisporus (J.E. Lange) Imbach identified by LC-MS/MS. Food Chem. 2014, 148, 396-401.

37. Thewissen, B.G.; Pauly, A.; Celus, I.; Brijs, K.; Delcour, J.A. Inhibition of angiotensin I-converting enzyme by wheat gliadin hydrolysates. Food Chem. 2011, 127, 1653-1658.

38. Vercruysse, L.; Smagghe, G.; van der Bent, A.; van Amerongen, A.; Ongenaert, M.; van Camp, J. Critical evaluation of the use of bioinformatics as a theoretical tool to find high-potential sources of ACE inhibitory peptides. Peptides 2009, 30, 575-582.

39. Ojagh, S.M.; Núñez-Flores, R.; López-Caballero, M.E.; Montero, M.P.; Gómez-Guillén, M.C. Lessening of high-pressure-induced changes in Atlantic salmon muscle by the combined use of a fish gelatin-lignin film. Food Chem. 2011, 125, 595-606.

40. Martinez, I.; Slizyte, R.; Dauksas, E. High resolution two-dimensional electrophoresis as a tool to differentiate wild from farmed cod (Gadus morhua) and to assess the protein composition of klipfis. Food Chem. 2007, 102, 504-510.

41. Lin, W.F.; Lyu, Y.C.; Wu, Y.J.; Lu, C.H.; Hwang, D.-F. Species identification of snapper: A food poisoning incident in Taiwan. Food Control 2012, 25, 511-515.

42. Almaas, H.; Eriksen, E.; Sekse, C.; Comi, I.; Flengsrud, R.; Holm, H.; Jensena, E.; Jacobsena, M.; Langsruda, T.; Vegarud, G.E. Antibacterial peptides derived from caprine whey proteins, by digestion with human gastrointestinal juice. Br. J. Nutr. 2011, 106, 896-905.

43. Inglingstad, R.A.; Devold, T.G.; Eriksen, E.K.; Holm, H.; Jacobsen, M.; Liland, K.H.; Rukke, E.O.; Vegarud, G.E. Comparison of the digestion of caseins and whey proteins in equine, bovine, caprine and human milks by human gastrointestinal enzymes. Dairy Sci. Technol. 2010, 90, 549-563. 
44. Eriksen, E.K.; Holm, H.; Jensen, E.; Aaboe, R.; Devold, T.G.; Jacobsen, M.; Jacobsen, M.; Vegarud, G.E. Different digestion of caprine whey proteins by human and porcine gastrointestinal enzymes. Br. J. Nutr. 2010, 104, 374-381.

45. Khantaphant, S.; Benjakul, S.; Ghomi, M.R. The effects of pretreatments on antioxidative activities of protein hydrolysate from the muscle of brownstripe red snapper (Lutjanus vitta). LWT Food Sci. Technol. 2011, 44, 1139-1148.

46. Nakajima, K.; Yoshie-Stark, Y.; Ogushi, M. Comparison of ACE inhibitory and DPPH radical scavenging activities of fish muscle hydrolysates. Food Chem. 2009, 114, 844-851.

47. Roepstorff, P.; Fohlman, J. Proposal for a common nomenclature for sequence ions in mass spectra of peptides. Biomed. Mass Spectrom. 1984, 11, 601.

48. Matsui, T.; Liang, C.H.; Tanaka, T.; Maki, T.; Osajima, Y.; Matsumoto, K. Depressor effect of wheat germ hydrolysate and its novel angiotensin I-converting enzyme inhibitory peptide, Ile-Val-Tyr, and the metabolism in rat and human plasma. Biol. Pharm. Bull. 2000, 23, 427-431.

49. Alves, G.; Ogurtsov, A.Y.; Kwok, S.; Wu, W.W.; Wang, G.; Shen, R.F.; Yu, Y.-K. Detection of co-eluted peptides using database search methods. Biol. Direct 2008, 3, 27.

50. Seidler, J.; Zinn, N.; Boehm, M.E.; Lehmann, W.D. De novo sequencing of peptides by MS/MS. Proteomics 2010, 10, 634-649.

51. Kebarle, P.; Verkerk, U.H. Electrospray: From ions in solution to ions in the gas phase, what we know now. Mass Spectrom. Rev. 2009, 28, 898-917.

52. Johnson, P.E.; Baumgartner, S.; Aldick, T.; Bessant, C.; Giosafatto, V.; Heick, J.; Mamone, G.; O'Connor, G.; Poms, R.; Popping, B.; et al. Current perspectives and recommendations for the development of mass spectrometry methods for the determination of allergens in foods. J. AOAC Int. 2011, 94, 1026-1033.

53. Minkiewicz, P.; Miciński, J.; Darewicz, M.; Bucholska, J. Biological and chemical databases for research into the composition of animal source foods. Food Rev. Int. 2013, 29, 321-351.

54. Boulesteix, A.-L. Over-optimism in bioinformatics research. Bioinformatics 2010, 26, 437-439.

55. Tulipano, G.; Sibilia, V.; Caroli, A.M.; Cocchi, D. Whey proteins as source of dipeptidyl dipeptidase IV (dipeptidyl peptidase-4) inhibitors. Peptides 2011, 32, 835-838.

56. Gallardo, J.M.; Ortea, I.; Carrera, M. Proteomics and its applications for food authentication and food-technology research. Trends Anal. Chem. 2013, 52, 135-141.

57. Mallick, P.; Schirle, M.; Chen, S.S.; Flory, M.R.; Lee, H.; Martin, D.; Ranish, J.; Raught, B.; Schmitt, R.; Werner, T.; et al. Computational prediction of proteotypic peptides for quantitative proteomics. Nat. Biotechnol. 2007, 25, 125-131.

58. Darewicz, M.; Minkiewicz, P.; Dziuba, M.; Panfil, T. Application of second and fourth derivatives of UV spectra to identify low molecular weight products of $\beta$-casein hydrolysis by plasmin. Zywnosc. Nauk. Technol. Jakosc. 2012, 4, 151-160.

59. Udenigwe, C.C.; Howard, A. Meat proteome as source of functional biopeptides. Food Res. Int. 2013, 54, 1021-1032.

60. Szabó, A.; Sahin-Tóth, M. Determinants of chymotrypsin C cleavage specificity in the calcium-binding loop of human cationic trypsinogen. FEBS J. 2012, 279, 4283-4292.

61. Hur, S.J.; Lim, B.O.; Decker, E.A.; McClements, D.J. In vitro human digestion models for food applications. Food Chem. 2011, 125, 1-12. 
62. UniProt database. Available online: http://www.uniprot.org (accessed between March and June 2012).

63. Larkin, M.A.; Blackshields, G.; Brown, N.P.; Chenna, R.; McGettigan, P.A.; McWilliam, H.; Valentin, F.; Wallace, I.M.; Wilm, A.; Lopez, R.; et al. Clustal W and Clustal X version 2.0. Bioinformatics 2007, 23, 2947-2948.

64. ClustalW2-Multiple Sequence Alignment software. Available online: http://www.ebi.ac.uk/Tools/ msa/clustalw2/ (accessed between March and June 2012).

65. Minkiewicz, P.; Dziuba, J.; Iwaniak, A.; Dziuba, M.; Darewicz, M. BIOPEP database and other programs for processing bioactive peptide sequences. J. AOAC Int. 2008, 91, 965-981.

66. BIOPEP database. Available online: http://uwm.edu.pl/biochemia (accessed between July and October 2012).

67. Kyte, J.; Doolittle, R.F. A simple method for displaying the hydropathic character of a protein. J. Mol. Biol. 1982, 157, 105-132.

68. Carrera, M.; Cañas, B.; Piñeiro, C.; Vázquez, J.; Gallardo, J.M. Identification of commercial hake and grenadier species by proteomic analysis of the parvalbumin fraction. Proteomics 2006, 6, 5278-5287.

69. Almaas, H.; Cases, A.-L.; Devold, T.G.; Holm, H.; Langsrud, T.; Aabakken, L.; Aadnoeyd, T.; Vegaruda, G.E. In vitro digestion of bovine and caprine milk by human gastric and duodenal enzymes. Int. Dairy J. 2006, 16, 961-968.

70. Almaas, H.; Holm, H.; Langsrud, T.; Flengsrud, R.; Vegarud, G.E. In vitro studies of the digestion of caprine whey proteins by human gastric and duodenal juice and the effects on selected microorganisms. Br. J. Nutr. 2006, 96, 562-569.

71. Ulleberg, E.K.; Comi, I.; Holm, H.; Herud, E.B.; Jacobsen, M.; Vegarud, G.E. Human gastrointestinal juices intended for use in in vitro digestion models. Food Dig. 2011, 2, 52-61.

72. Sánchez-Chiang, L.; Cisternas, E.; Ponce, O. Partial purification of pepsins from adult and juvenile salmon fish Oncorhynchus keta. Effect of $\mathrm{NaCl}$ on proteolytic activities. Comp. Biochem. Physiol. 1987, 87, 793-797.

73. Krogdahl, A.; Holm, H. Inhibition of human and rat pancreatic proteinases by crude and purified soybean proteinase inhibitors. J. Nutr. 1979, 109, 551-558.

74. Kirschenbaum, D.M. Molar absorptivity and $\mathrm{A}^{1 \%}{ }_{1 \mathrm{~cm}}$ values for proteins at selected wavelengths of the ultraviolet and visible regions. XI. Anal. Biochem. 1975, 68, 465-484.

75. Bradford, M.M. A rapid and sensitive method for the quantitation of microgram quantities of protein utilizing the principle of protein-dye binding. Anal. Biochem. 1976, 72, 248-254.

76. Laemmli, U.K. Cleavage of structural proteins during the assembly of the head of bacteriophage T4. Nature 1970, 227, 680-685.

77. Jimsheena, V.K.; Gowda, L.R. Colorimetric, high-throughput assay for screening angiotensin I-converting enzyme inhibitors. Anal. Chem. 2009, 81, 9388-9394.

78. Nakamura, Y.; Yamamoto, N.; Sakai, K.; Okubo, A.; Yamazaki, S.; Takano, T. Purification and characterization of angiotensin I-converting enzyme inhibitors from sour milk. J. Dairy Sci. 1995, 78, 777-783.

79. Iwaniak, A. Analysis of relationship between the structure and ACE inhibitory activity food derived peptides. The evaluation of suitability of in silico methods in the research on protein precursors of bioactive peptides. Olsztyn UW-M Olsztyn 2011, 162, 1-152. 
80. Savitzky, A.; Golay, M.J.E. Smoothing and differentiation of data by simplified least squares procedures. Anal. Chem. 1964, 36, 1627-1639.

81. Krokhin, O. V Sequence-specific retention calculator. Algorithm for peptide retention prediction in ion-pair RP-HPLC: Application to 300- and 100-A pore size C18 sorbents. Anal. Chem. 2006, 78, 7785-7795.

82. Spicer, V.; Yamchuk, A.; Cortens, J.; Sousa, S.; Ens, W.; Standing, K.G.; Wilkins, J.A.; Krokhin, O.V. Sequence-specific retention calculator. A family of peptide retention time prediction algorithms in reversed-phase HPLC: Applicability to various chromatographic conditions and columns. Anal. Chem. 2007, 79, 8762-8768.

83. Sequence Specific Retention Calculator. SSRCalc Software. Available online: http:/hs2.proteome.ca/ SSRCalc/SSRCalcX.html (accessed between March and May 2013).

84. Fragment Ion Calculator application. Available online: http://db.systemsbiology.net:8080/ proteomicsToolkit/FragIonServlet.html (accessed between March and May 2013).

85. Monaci, L.; Losito, I.; Palmisano, F.; Visconti, A. Reliable detection of milk allergens in food using a high-resolution, stand-alone mass spectrometer. J. AOAC Int. 2011, 94, 1034-1042.

(C) 2014 by the authors; licensee MDPI, Basel, Switzerland. This article is an open access article distributed under the terms and conditions of the Creative Commons Attribution license (http://creativecommons.org/licenses/by/3.0/) 